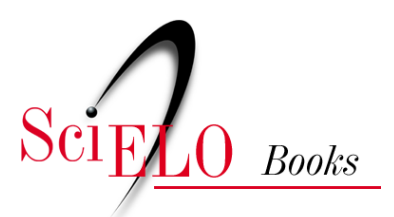

\title{
Índio Condá
}

\author{
José Carlos Radin \\ Gentil Corazza
}

RADIN, J.C., and CORAZZA, G. Índio Condá. In: Dicionário histórico-social do Oeste catarinense [online]. Chapecó: Editora UFFS, 2018, pp. 84-86. ISBN: 978-85-64905-65-8.

https://doi.org/10.7476/9788564905658.0019.

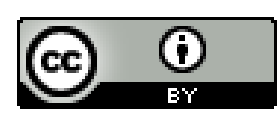

All the contents of this work, except where otherwise noted, is licensed under a Creative Commons Attribution 4.0 International license.

Todo o conteúdo deste trabalho, exceto quando houver ressalva, é publicado sob a licença Creative Commons Atribição $\underline{4.0}$.

Todo el contenido de esta obra, excepto donde se indique lo contrario, está bajo licencia de la licencia $\underline{\text { Creative Commons }}$ Reconocimento 4.0. 


\section{Índio Condá}

Vitorino Condá nasceu nos campos de Guarapuava, em 1805, e morreu em sua aldeia nas margens do Rio Chapecó, nos campos de Palmas, em 1870, com 65 anos de idade. Foi cacique da tribo Kaingang, um importante líder indígena, que se notabilizou durante o processo de ocupação das terras indígenas do Oeste catarinense por fazendeiros e autoridades imperiais, principalmente a partir de meados do Século XIX.

A ocupação do território Kaingang causou muita tensão e conflito na região. A frente pastoril de ocupação, apoiada pelas autoridades imperiais, praticava uma verdadeira política de extermínio contra os indígenas, mas ao mesmo tempo procurava aliciar os que eram dóceis e estavam dispostos a colaborar com o processo de ocupação. Assim, a referida ocupação dividiu o povo indígena entre os favoráveis e os contrários a uma aliança com os brancos, que manipulavam as divisões internas dos indígenas para consolidarem a tomada do território. Condá tinha uma grande ascendência sobre os demais caciques e os diversos grupos Kaingang (RIESEMBERG, 1978) e, como tal, se transformou numa peça-chave do processo de conquista do Oeste, nos Campos de Palmas.

$\mathrm{Na}$ realidade, os povos indígenas não tinham muitas alternativas. Podiam fugir de suas terras, abandonando tudo o que era seu, resistir, serem escravizados ou simplesmente eliminados, ou ainda aceitar a ocupação e integrar-se na nova situação, aldeando-se em vilas como queriam os invasores. Na luta de resistência, eram comuns os sequestros tanto de índios como de fazendeiros. Conta-se que, em 1843, Condá foi instado pelo comandante da Polícia em Palmas a ajudar no resgate do tropeiro capitão José de Sá Soutto-Maior das mãos de indígenas que habitavam as proximidades.

Foi nesse contexto de invasão, conflito e extermínio que se destacou o papel do cacique Condá. Como superar o dilema do seu povo de resistir e ser eliminado ou fazer acordo com os invasores e tentar sobreviver? Condá operou nesta trama bastante complexa. Ele atuava 
mais como peça de uma grande engrenagem, movida por interesses muito poderosos. As múltiplas facetas do papel de Vitorino Condá só são compreensíveis se for levada em conta a correlação de forças entre governantes, povoadores locais e os próprios indígenas. As relações de poder eram muito desiguais e os interesses recíprocos bastante diversos. Os povos indígenas eram o elo mais fraco numa guerra para manter suas terras e salvar suas vidas. Ao governo interessava fortalecer a ocupação de um território de fronteira em disputa com a Argentina e Condá era uma peça chave de permanência brasileira nos Campos de Palmas (D’ANGELIS, 2006). Já aos brancos invasores interessava a apropriação das terras indígenas, valendo-se ao mesmo tempo do conhecimento do território e da experiência dos caciques para "pacificar" índios e fazê-los aceitar a ocupação e a convivência com os invasores.

É nesse contexto que se pode compreender a posição ambígua, controversa e até contraditória de Condá, que oscilava entre a colaboração e a hostilidade, dependendo da situação, muitas vezes até lutando contra seus próprios companheiros indígenas, conforme o jogo de interesses que permeavam as posições de cada parte. O próprio Condá às vezes era tratado pelas autoridades policiais da região como assassino e assaltante e outras vezes como pacificador e colaborador. Segundo algumas versões, Condá teria aceitado a ocupação, colaborando no aldeamento dos indígenas durante o processo de ocupação de suas terras. Para Santos (1970), não resta dúvida que Condá havia aceitado a convivência pacífica com os fazendeiros em Guarapuava. Seu papel colaboracionista ficará marcado no apoio à penetração brasileira nos Campos de Palmas e, em seguida, de Nonoai, no Rio Grande do Sul. No entanto, segundo outras versões, a colaboração de Condá teria sido apenas uma estratégia de sobrevivência, face ao poderio do invasor. Como afirma Mota (2000), a colaboração com os brancos não significava que os índios fossem totalmente submissos e confiáveis.

Enfim, para avaliar o papel do cacique Condá, é preciso levar em conta esse contexto complicado em que estava inserido e a trama de interesses em que fora envolvido pelas autoridades e pelos colonizadores. As atitudes de Condá em geral eram bem-vistas por parte do governo. 


\section{REFERÊNCIAS}

D'ANGELIS, Wilmar da Rocha. Para uma história dos índios do oeste catarinense. CEOM: 20 anos de memórias e histórias no oeste de Santa Catarina. Cadernos do CEOM, Ano 19, n. 23 Chapecó: Unochapecó, 2006. MALAGE, Kátia Graciela J. M. Condá e Viri: chefias indígenas em PalmasPR, década de 1840. (Dissertação de Mestrado). Curitiba: UFPR, 2010. MOTA, Lúcio Taudeu. Os índios Kaingang e seus territórios nos campos do Brasil meridional na metade do século passado. In: MOTA, Lúcio Tadeu; NOELLI, Francisco S.; TOMMASINO, Kimiye (Org.). Uri e Wãxi: estudos interdisciplinares Kaingang. Londrina: UEL, 2000. RIESEMBERG, Alvir. A nau São Sebastião. Instituto Histórico, Geográfico e Etnográfico Paranaense. Curitiba, 1978.

SANTOS, Sílvio Coelho dos. A integração do índio na sociedade regional: a função dos postos indígenas em Santa Catarina. Florianópolis: UFSC, 1970. 